\title{
走査型透過 X 線顕微鏡（STXM）のポリマー材料への応用 Application of Scanning Transmission X-ray Microscopy on Polymer Materials
}

\section{1.はじめに}

ポリマーブレンドやナノコンポジット材料の開発におい て, その相分離やドメイン構造の界面を正しく観察するこ とは極めて重要である。これら界面を観察するため，古く から使われている手法として, 断面の電子顕微鏡観察が あげられる。電子顕微鏡には，走査型（SEM），透過型 (TEM) があることは言うまでもないが, 近年では, 走査 型透過電子顕微鏡 (STEM: Scanning Transmission Electron Microscopy）が普及し, 高い空間分解能と元素分 析能力により，さまざまな材料に適用されている。

STEM は, 細く絞った電子線を薄片化した陚料上でス キャンしながら, 透過信号を検出する分析手法であるが, この STEM の “E” (電子線) のところを “X” (X 線) に 変えたものが, 本稿で紹介する, 走査型透過 X 線顕微鏡 (STXM: Scanning Transmission X-ray Microscopy) である。STXM（“スティクセム”, “スティクサム”など と呼ばれる。）においてもSTEM と同様に微細なビーム (STXM の場合はX 線ビーム) が必須であることから， $\mathrm{X}$ 線の光源としては通常, 放射光が用いられる。

STXM は 1990 年代初頭に米国で実用化され ${ }^{1)}$ ，その後， 韓国, スイス, ドイッ, カナダ, 英国など, 世界各国の放 射光施設で専用のビームラインが建設されている。これら の国々に比べて日本では導入が遅れていたが, 国内でも, 高エネルギー加速器研究機構の Photon Factory や分子科 学研究所の UVSOR-II など, 複数の施設で設置され ${ }^{2,3)}$, UVSOR-II では，一般ユーザー向けに公開が始まってい る。

\footnotetext{
*旭化成 (株) 基盤技術研究所

静岡県富士市鲛島 2-1 ₹ 416-8501

Analysis and Simulation Center, Asahi-KASEI Corporation 2-1 Samejima, Fuji, Shizuoka, 416-8501 Japan
}

\section{菊間淳* Jun KIKUMA}

STXM の特徴については次項で詳しく述べるが, 電子 線との比較という観点では次の 2 つがメリットとして挙げ られる。

（1）電子線に比べて試料に及ぼすダメージが少ない。

（2）化学結合状態に関する情報がより詳細に得られる。 上記 2 つの特徵は, 本稿で述べるポリマー材料を対象とす る場合は極めて重要である。実際, STXMの適用事例と してはポリマーや生物系試料など, 有機材料系のものが多 く, ポリマーの相分離やドメイン構造 ${ }^{4 \sim 6)}$, 繊維材料 ${ }^{7 \sim 9)}$, 有機半導体 ${ }^{10)}$, 生物系試料などにおいて様々な研究成果 が報告されている。また, 真空を必要としないため, 試料 を水中に置いた状態での測定も可能であり，水中における ミクロゲルや微生物の観察などにも用いられている ${ }^{11,12)} 。$

ここでは, STXMのいくつかの事例を紹介するととす に，これらを通じて接着/剥離現象解明のッールとしての STXMのポテンシャルについても述べてみたい。

\section{STXM の原理と特徵}

\section{1 概要}

STXM は, 集光したX 線ビームを薄片化したサンプル 上でスキャンしながら，透過信号を検出する手法である。

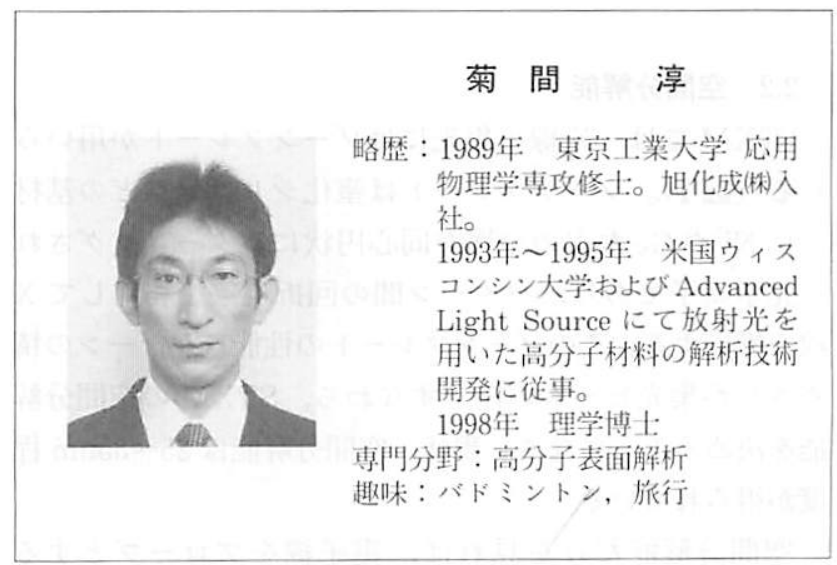




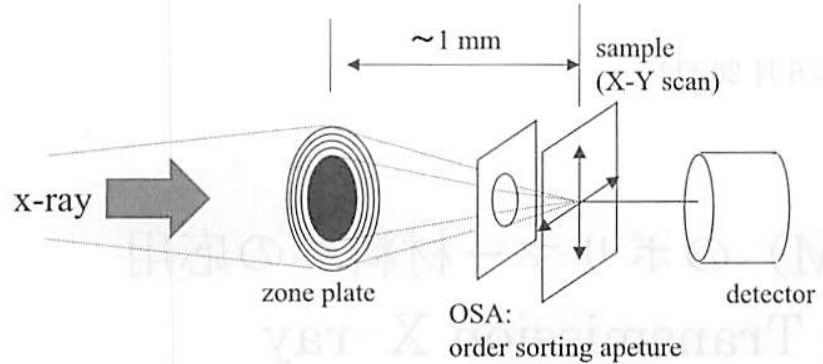

図 1 STXM の概念図

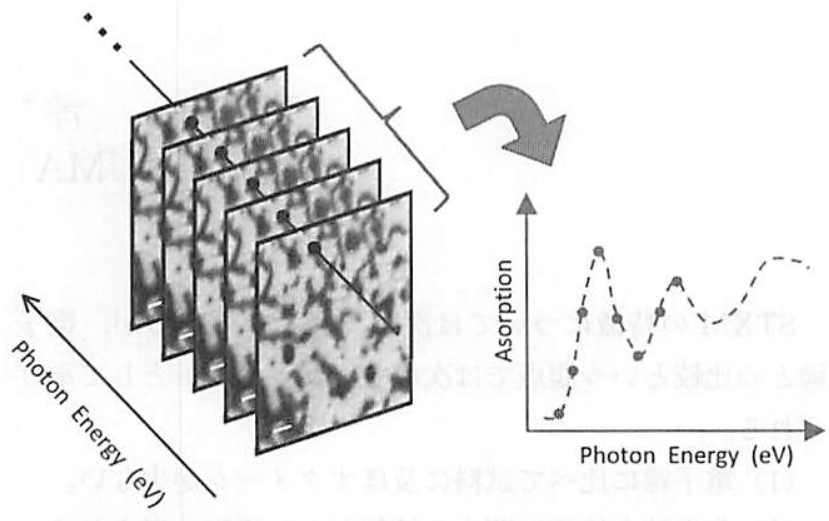

図 2 STXM におけるマッピングからのスペクトル抽出の 概念図

図 1 にその概念図を示す。ここで言う「透過信号」とは通 常，透過光強度を指す。すなわち，X 線の波長を固定し てサンプル上のある範囲で空間的に X 線ビームをスキャ ンすれば，その波長での X 線透過像が得られる。（透過光 強度と入射光強度との比をとれば, 容易に吸収強度のマッ ピング像に变換することも可能である。）一方，X 線ビー ムをサンプル上の 1 点に固定して入射 X 線の波長をスキャ ンすれば，その場所での X 線吸収スペクトルを得ること ができる。

さらに, これらの両方をスキャンすれば, 各ピクセルご とに吸収スペクトルが得られることになる。このピクセル ごとの吸収スペクトルを解析することにより，微小部にお ける化学状態の詳細情報を引き出すことができる。図 2 に その概念図を示した。

\section{2 空間分解能}

STXM では，X線の集光にはゾーンプレートが用いら れる（図 1)。ゾーンプレートは窒化シリコンなどの基材 上に $\mathrm{Ni}$ や $\mathrm{Ge}$ などの金属が同心円状にパターニングされ た光学素子であり,パターン間の回折現象を利用して X 線を集光する。このゾーンプレートの性能 (パターンの精 密さ）が集光ビームの径，すなわち， STXM の空間分解 能を決めることになる。現状, 空間分解能は $25 \sim 35 \mathrm{~nm}$ 程 度が得られている。

空間分解能だけを見れば，電子線をプローブとする
STEM と比べて 1 桁程度少るむのであるが, 次項で述 べる「分光分析法としての情報量」が電子線に比べて格 段に高いので，ここにSTXM の存在価值があるといえ る。

\section{3 吸収スペクトル（NEXAFS: Near Edge X-ray} Absorption Fine Structure)

STXM では光源に放射光を用いるので，入射 X 線の光 子エネルギー (波長) を容易に变化させることができる゙。 試料を構成する元素の内殼電子（ポリマーであれば， C の 1s 電子など）のイオン化エネルギーの近傍で入射 $\mathrm{X}$ 線の 光子エネルギーをスキャンすれば，あるしきい值以上で $\mathrm{X}$ 線の吸収がステップ状に増大する。このしきい值がい わゆる「吸収端」である（たとえば，「Cの K 殸吸収端」 と呼ぶ）。らに，この吸収端の近傍での X 線の吸収強度 を詳細にみると, 着目元素の化学結合状態に応じて, 吸収 スペクトルに微細構造が現れる。このスペクトルを「X 線吸収端近傍微細構造 (NEXAFS)」という。NEXAFS スペクトルの概念図を図 3 に示す。

また，いくつかの代表的なポリマーの C-K 殸吸収端近 傍のスペクトルを図 4 に示す ${ }^{13}$ )。 $\mathrm{C} 1 \mathrm{~s} \rightarrow$ 非占有準位（バン ド）の励起に相当するエネルギーで吸収ピークが観測され ており，ポリマーの種類によって，それぞれ異なる吸収ス ペクトルを示すことがわかる。

STXM では，この NEXAFS スペクトルが化学状態の 違いによって変化することを利用して, 微小部での化学状 態を解明する手段として用いられるのである。

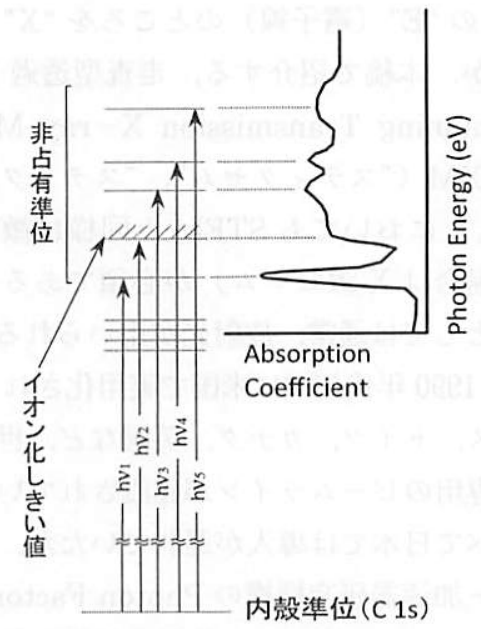

図 3 ポリマーの NEXAFS スペクトルの概念図

※光子 (photon) エネルギー $\mathrm{E}$ と波長 $\lambda$ との間には, $\mathrm{E}=\mathrm{hc} / \lambda$ $(\mathrm{h}$ ：プランク定数, $\mathrm{c}$ ：光速）の関係があり, $\mathrm{X}$ 線吸収分光の 分野では X 線のエネルギーを入ではなく $\mathrm{E}$ で記述することが 多い。本稿でも，これ以降，X線のエネルギーの表記には，波 長ではなく photon energy $(\mathrm{eV})$ を用いる。 


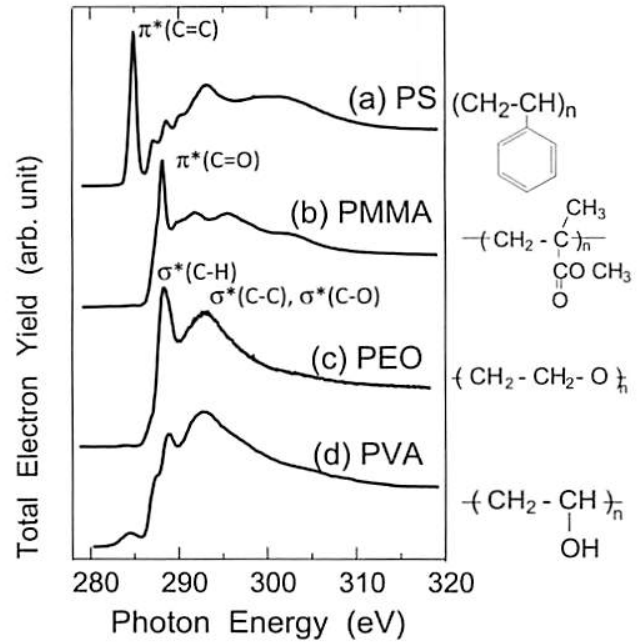

図 4 ポリマーの NEXAFS スペクトルの例 13)

a) ポリスチレン, b) ポリメチルメタクリレート,

c) ポリエチレンオキシド，d）ポリビニルアルコール

\section{4 測定雾囲気}

STXM ではサンプルを真空中に置く必要はない。X 線 は, 大気圧下でも数 $\mathrm{mm}$ の距離であれば雾囲気ガスによ る吸収を比較的少なく抑えることができるからである。 あちろんこれは, X線の光子ェネルギー（以降, photon energy と表記）や雾囲気ガスの種類によって異なる。多 くの STXM が用いられている超軟 X 線の photon energy 領域では, 吸収の少ない He ガスに置換するなどの方法が 用いられる。いずれにしてむ, 試料を真空下に置かなくて よいというのは大きなメリットである。また，数 $\mu \mathrm{m} の$ 厚さであれば, 水も透過することができるので, 試料を濡 れた状態に保持したまま測定をすることも可能である。

\section{3. ポリマー分野での STXM 活用例}

\section{1 アクリル系難燃繊維の化学状態解析 ${ }^{8)}$}

ポリアクリロニトリル（PAN）䋞維を適度な温度で焼 成することにより，柔軟性と難燃性を兼ね備えた難燃織維 を作ることができる。燒成途中段階での織維断面を観察す ると，コア/シェル構造を有することがわかっている。コ ア部とシェル部で化学状態によ゙のような違いがあるのかを STXM を用いて調べた。

焼成前の PAN 織維, 焼成初期, 焼成終期の繊維を, 各々 樹脂に包埋し, 厚さ約 $100 \mathrm{~nm}$ の切片にして STXM 测定 を行った。

図 5 に各試料中央部（コア）における $\mathrm{C}-\mathrm{K}$ 殻吸収端の NEXAFS スペクトルを示す。 $\mathrm{C} \equiv \mathrm{N}$ 基由来のピークと $\mathrm{C}=$ $\mathrm{C}$ 基由来のピークに着目すると, 焼成が進むにつれて二ト リル基が減少し，代わって $\mathrm{C}=\mathrm{C}$ が増大する傾向があるこ とがわかる。このことは，二トリル基が $-\mathrm{C}=\mathrm{N}$-構造とな り,さらに環化が進んでグラファイトライクな構造が生じ る，という従来の焼成メカニズムを支持するものである。

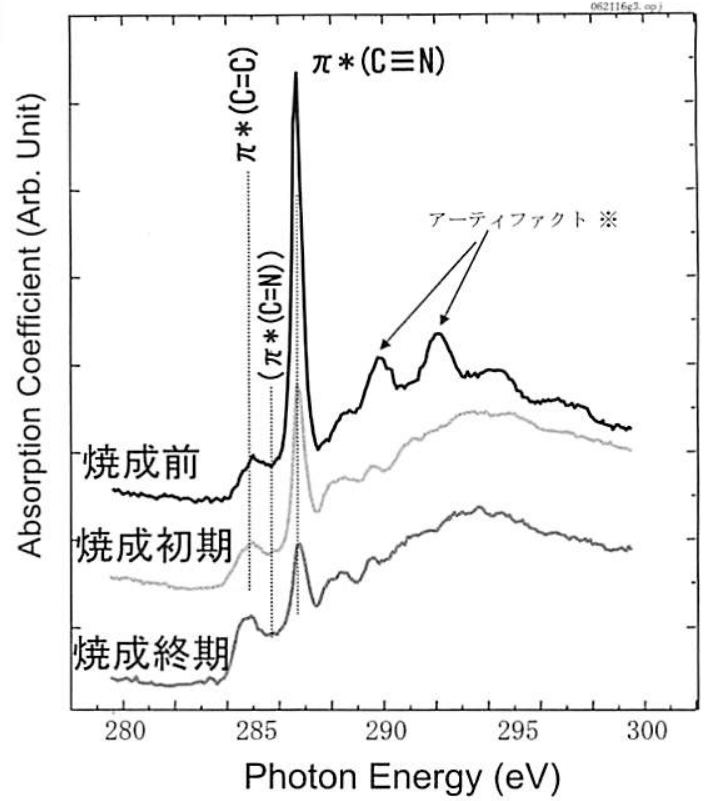

図 5 アクリル織維断面中央部における $\mathrm{C}-\mathrm{K}$ 凯 NEXAFS スペクトル

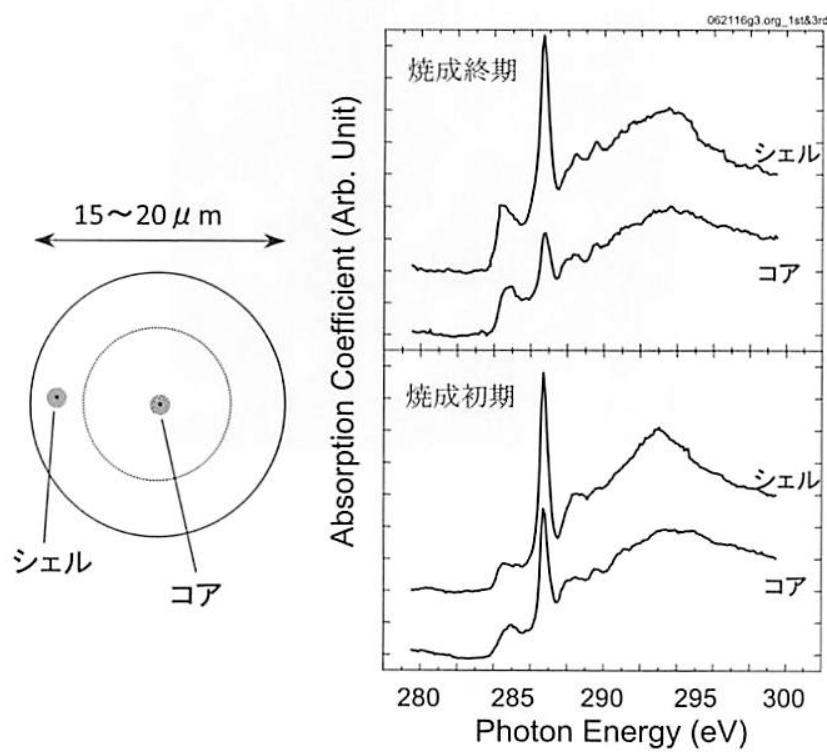

図 6 焼成初期，焼成終期段階の繊維断面における $\mathrm{C}-\mathrm{K}$ 凯 NEXAFS スペクトル

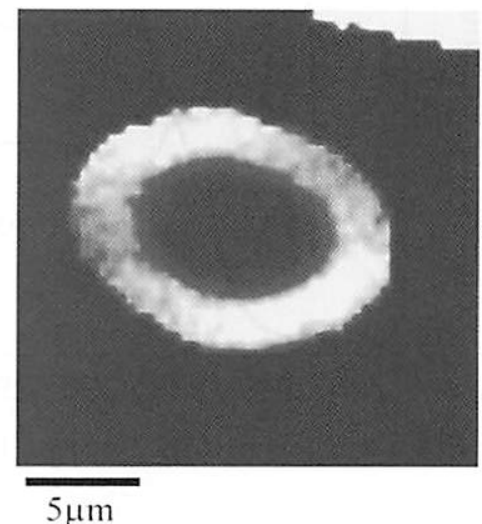

図 7 焼成終期段階の織維断面における $\mathrm{C}-\mathrm{K}$ 殻 NEXAFS スペクトル 
図 6 には焼成初期および終期のコア部とシェル部のスペク トルを示す。どちらのサンプルにおいても, コア部では二 トリル基の量が少ないことがわかる。ニトリル基のピーク に photon energy を固定してSTXM 像を测定し, 吸収強 度のマッピングに变換したものが図 7 である。図 7 から, コアノシェル構造がニトリル基の存在量の違い（焼成進度 の違い）を反映したむのであることが明らかになった。コ ア部の方が燒成が早く進むという予想外の結果であったが, 後に表面よバルクの IR 分析の比較により結果の正しさが 確認されている8)。

\section{2 中空糸膜における親水性ポリマーの分布解析}

ポリスルホン (PSF) とポリビニルピロリドン (PVP) からなる中空糸多孔膜の断面において各成分の分布を調べ た。

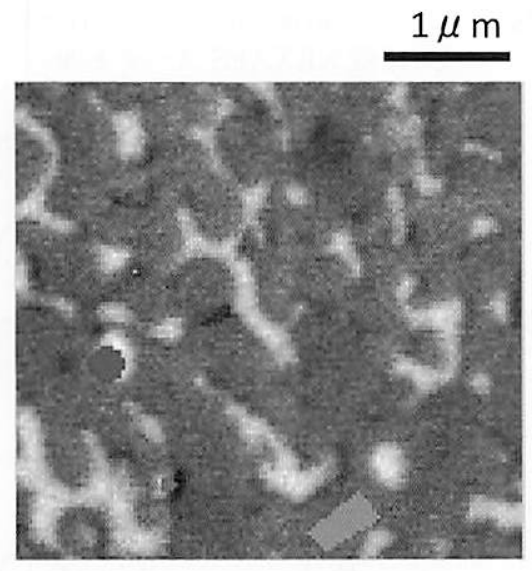

図 8

$\mathrm{h} \nu=285.4 \mathrm{eV}$ における吸収強度マッピング

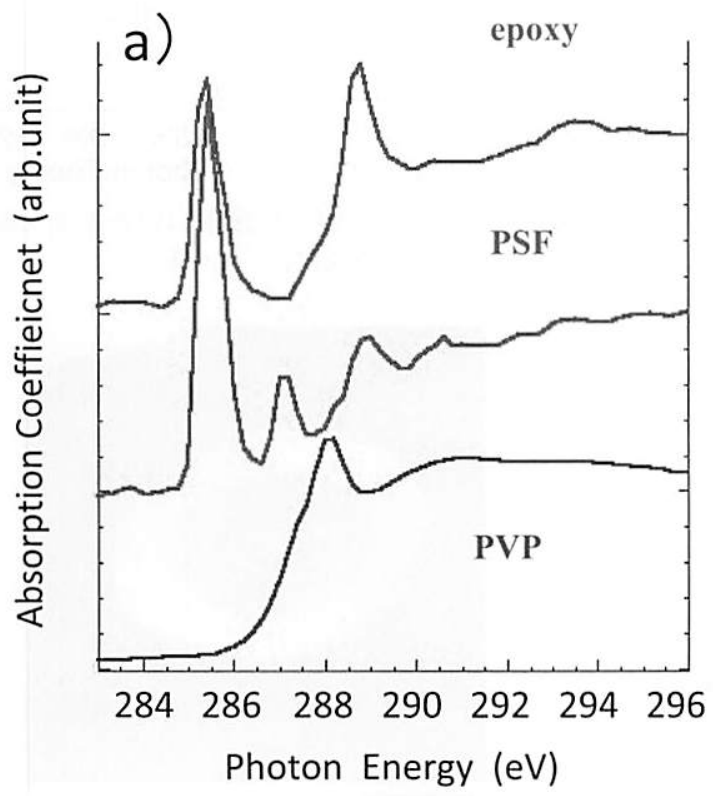

空孔部をエポキシ樹脂で埋めた後, 切片を作製した試料 について, $283 \mathrm{eV}$ から $296 \mathrm{eV}$ まで $0.2 \mathrm{eV}$ の photon energy 間隔で STXM 像を取得し, 各ピクセルの $\mathrm{C}-\mathrm{K}$ 款 吸収端のスペクトルデータセットを得た。

図 8 に photon energy $285.4 \mathrm{eV}(\mathrm{C}=\mathrm{C})$ で得られた吸収 強度マッピングを示す。この photon energy ではPSF の 吸収強度が強く（図では明るく）観測され，マトリックス であるエポキシ樹脂とのコントラストが明確に観測されて いる。PSF およびェポキシ樹脂と思われるエリア（PSF： 緑, エポキシ：茶）に打けるスペクトルを各々抽出し, 図 9 (a) に示した。PVPが単独に存在するエリアは明確に観 測されなかったため, 別途测定したPVP の吸収スペクト ルと合わせて，図 9 (a) に示す。

各ピクセルにおけるスペクトルを, 構成成分の純スペク トルの線形結合と考えて解析を行うことにより, 各成分の マッピングを得た（図 9(b))。その結果，エポキシ樹脂 とPSF の界面（すなわち, PSF の表面）にPVPが偏在 していることが示された。

\section{3 ポリプロピレン/クレイ/エラストマー ナノコンポジットにおける分散状態と界面構造 ${ }^{14}$}

有機/無機コンポジット材料においては, 各ポリマー成 分やフィラーの分散性を向上させるため, 各成分に表面処 理を施したり，相溶化剂が添加される。Hitchcock らの研

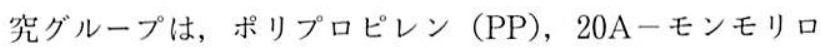
ナイト（有機物で改質したもの）, スチレンーエチレンブ チレンースチレンブロックコポリマー（SEBS）の 3 元系 コンポジットに相溶化㓮として, 無水マレイン酸グラフト

図 9 a) 各成分の NEXAFS スペクトル

エポキシ樹脂, PSF はマッピングデータより抽出。

PVP は別途測定したもの。

b）成分別マッピング (赤 : epoxy, 緑：PSF, 青 : PVP) 
PP またはプラズマ処理 PP を添加した系おいて，各成分 の偏析挙動や分散状態を調べた。

図 10 に各成分の $\mathrm{C}-\mathrm{K}$ 殻 NEXAFS スペクトルを示す。 スペクトルは各々の成分ごとに特徴的なピークを示してお り, ナノ領域で識別が可能であることが期待される。ここ で，20A-モンモリロナイトの C-K 殸における吸収は， 改質に用いられた有機物によるものである。

図 11 に，2 種のコンポジットの成分別マッピングを示 す。図 11 (a) は，相溶化剂として，無水マレイン酸グラ フトPPを5wt.\%添加したもの，図 11 (b) は，15wt.\%添

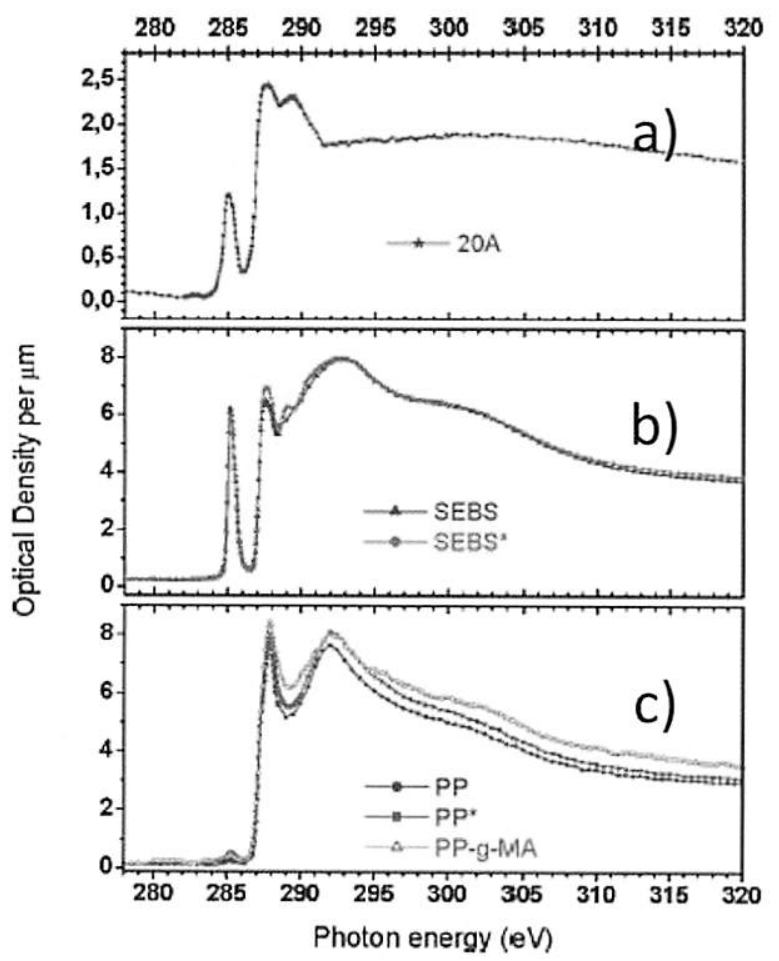

図 10 各成分の C K 殼 NEXAFS スペクトル ${ }^{14)}$ a) 20A-モンモリロナイト, b) SEBS ブロックコポリマー, c）ポリプロピレンおよび变性 PP 相溶化剤

(Z. Martin et. al., Macromolecules, 44, 2179 (2011) より許可 を得て転載。Copyright (2011) American Chemical Society.)
加したものである。どちらの系においても，PP マトリッ クス中に SEBS がドメインを形成して存在し，モンモリ ロナイトはSEBSドメインの界面に偏析していることが わかる。相溶化剤の量が多い図 11 (b) では, SEBSのド メインサイズが小さくなり, モンモリロナイトの界面偏析 量む少なくなっている。これは，相溶化剂としてのマレイ ン酸グラフトPPがモンモリロナイトにインターカレート して，PPマトリックス中に微分散しているためと考えら れる。

このように, 複雑な多元系における分散状態や偏析状態 を把握することにより，物性の改良につなげることができ ると考えられる。

\section{4. おわりに}

以上, 走查型透過 X 線顕微鏡 (STXM) のポリマー分 野への適用について述べてきた。今回紹介した事例や文献 は, 接着現象を直接研究したものではないが, 異種界面に おける特定成分の偏析などはすでに多くの実例がある。 また, データ解析技術の進歩により, 定量的な議論が可能 になってきていることから，接着界面における相互拡散な どについても今後, 有効な知見が得られるものと期待され る。さらに，本稿では説明を割愛したが，X線の偏光を 利用して官能基の配向に関する情報を得ることも可能であ $3^{7,10)}$ 。

これまで，海外の放射光施設でしか利用できなかった STXM であるが，国内の放射光施設で相次いで稼働する のを機に, 微小部の化学状態の研究手段として身近なもの になってくれることを期待したい。

$$
\text { 文献 }
$$

1) H. Ade, X. Zhang, S. Cameron, C. Costello, J. Kirz and S. Williams, Science, 258, 972 (1992).

2）小野寛太, PF 研究会「顕微分光研究の新展開」講演予稿集 (2012).

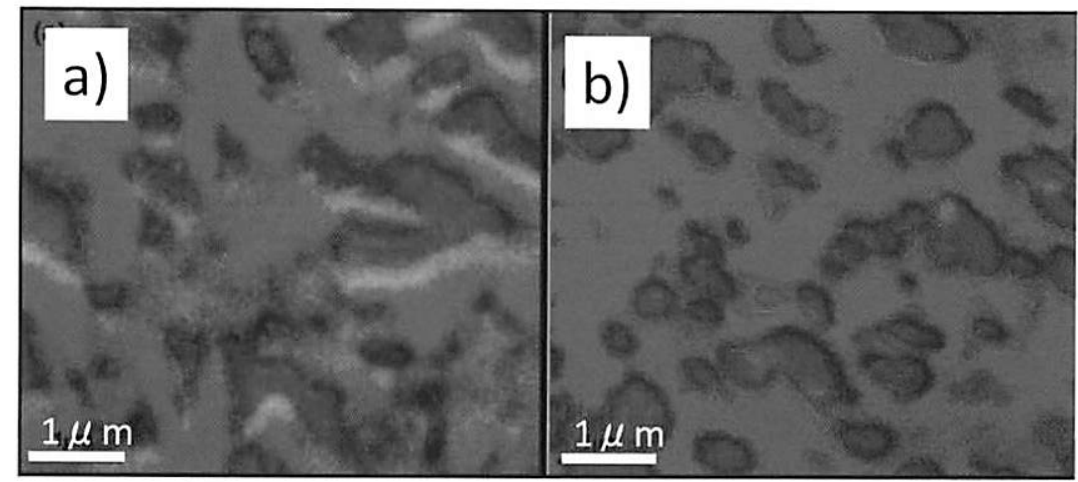

図 11 各成分別のカラーマッピング ${ }^{14}$

(緑：PP, 青: SEBS, 赤: $20 \mathrm{~A}$ モンモリロナイト) a）変性 PP 相溶化剂 5 wt.\%添加, b) 15 wt.\%添加,

(Z. Martin et. al., Macromolecules, 44, 2179 (2011) より許可を得て転載。 Copyright (2011) American Chemical Society.) 
3）大東琢治, PF 研究会「顕微分光研究の新展開」講演予稿集 (2012).

4) E. G. Rightor, S. G. Urquhart, A. P. Hitchcock, H. Ade, A. P. Smith, G. E. Mitchell, R. D. Priester, A. Aneja, G. Appel, G. Wilkes and W. E. Lidy, Macromolecules, 35, 5873 (2002).

5) A. P. Hitchcock, C. Morin, Y. M. Heng, R. M. Cornelius and J. L. Brash, J. Biomater. Sci. Polymer Edn., 13, 919 (2002).

6) N. Iwata, K. Tani, A. Watada, H. Ikeura-Sekiguchi, T. Araki and A. P. Hitchcock, Micron, 37, 290 (2006).

7) H. Ade and B. Hsiao, Science, 262, 1427 (1993).

8) J. Kikuma, T. Warwick, H-J. Shin, J. Zhang and B. P. Tonner, J. Electron Specrty. Relat. Phenom., 94, 271 (1998).
9) M. E. Rousseau, D. Hernandez-Cruz, M. M. West, A. P. Hitchcock and M. Pezolet, J. Am. Chem. Soc., 129, 3897 (2007).

10) B. Brauer, A. Virkar, S. C. B. Mannsfeld, D. P. Bernstein, R. Kukreja, K. W. Chou, T. Tyliszczak, Z. Bao and Y. Acremann, Chem. Mater., 22, 3693 (2010).

11) S. Fujii, S. P. Armes, T. Araki and H. Ade, J. Am. Chem. Soc., 127, 16808 (2005).

12) T. H. Yoon, S. B. Johnson, K. Benzerara, C. S. Doye. T. Tyliszczak, D. K. Shuh and G. E. Brown, Jr., Langmuir, 20, 10361 (2004).

13) J.Kikuma and B.P. Tonner, J.Electron Spectrosc. Relat. Phenom., 82, 53 (1996).

14) Z. Martin, I. Jimenez, M. A. Gomez-Fatou, M. West and A. P. Hitchcock, Macromolecules, 44, 2179 (2011). 